Jpn. J. Vet. Sci. 43, 63 70 (1981)

\title{
Growth Characteristics of Feline Panleukopenia Virus in Synchronized Kitten Kidney Cells
}

\author{
Makoto ENDO, Morikazu SHINAGAWA*, Hitoshi GOTO \\ and Kiheiji SHIMIZU \\ Department of Veterinary Microbiology and *Department of Veterinary \\ Public Health, School of Veterinary Medicine, Obihiro University of \\ Agriculture and Veterinary Medicine, Obihiro-shi, Hokkaido 080
}

(Received for publication July 11, 1980)

\begin{abstract}
The replication of feline panleukopenia virus (FPLV) in the synchronized kitten kidney $(\mathrm{KK})$ cells was studied. The adsorption rates of $\left[{ }^{3} \mathrm{H}\right]$-thymidine-labeled FPLV to each of the $G_{1}$, early $S$ and $M$ phases of cell cycle were almost the same. The $\mathrm{KK}$ cells maintained in the $\mathrm{G}_{1}$ phase did not support the replication of FPLV through the 12 to 36 hours of the observation period. However, when the cell cycle was allowed to proceed by trypsinizing $G_{1}$ phase cells at 0,6 and 12 hours after virus infection, a slight replication of the virus was observed. A high replication of FPLV was obtained from the cells infected at early $S$ phase. The early $S$ phase cells arrested with $2 \mathrm{mM}$ thymidine (TdR) also supported well the growth of FPLV when the initiation of the cell cycle was performed by the removal of TdR within 12 hours after infection, early $S$ phase arrested cells themselves did not. No replication of FPLV was observed in the M phase cells. These results indicate that FPLV requires the DNA synthesizing system of KK cells for its replication.
\end{abstract}

It is known that the actively dividing cellular function are required for maximal replication of FPLV, and that the infected confluent monolayer cultures show very low cytopathic effect of the virus. Therefore, the replication can be increased by inoculation of the virus before the cell cultures become confluent [5]. Recently, it was reported that the synthesis of Kilham rat virus was influenced by the level of cellular metabolic activity, probably DNA synthesis $[14,15]$, and also that the optimum replication of several non-defective parvoviruses which are able to replicate without aid of a helper virus depends upon the physiological state of the host cells $[9,13,15]$. Moreover, it was demonstrated that the higher yield of parvovirus LuIII and bovine parvovirus was obtained when synchronized cells of the early to mid $S$ phase were in- fected with the viruses in compared with that of the asynchronous cell cultures [8, 13].

In this report, the effects of the physiological state of the host cells on the multiplication of FPLV were studied.

\section{Materials and Methods}

Preparation of cell cultures

Secondary cultures of KK cells were used throughout the experiments, after the primary KK cells were prepared by the multiple extraction method [17]. The cells were derived from the cortex of the young cat kidney (within 50 days old). The primary $\mathrm{KK}$ cells were cultured in Roux bottles with Earle's salt solution containing $0.5 \%$ lactalbumin hydrolysate (LE) and $10 \%$ calf serum for 2 days, then the medium was replaced with medium 199 containing $10 \%$ calf serum. To prepare the secondary cultures, the confluent monolayer of cells was treated with $0.25 \%$ trypsin- $-0.02 \%$ EDTA. The detached cells collected were suspended in medium 199 containing $10 \%$ calf serum to a concentration of $5 \times 10^{5}$ cells $/ \mathrm{m} l$. Two $\mathrm{m} l$ each of the suspension 
were seeded into $35 \times 10 \mathrm{~mm}$ plates, $15 \mathrm{ml}$ each into $90 \times 15 \mathrm{~mm}$ petri dishes and $50 \mathrm{~m} l$ each into Roux bottles.

\section{Preparation of stock FPLV}

The cell suspension in $10 \mathrm{~m} l$ of medium 199 (cell density: about $1 \times 10^{7} / \mathrm{m} l$ ) prepared from the primary KK cultures was mixed with an equal volume of PPLV strain Obihiro, about $10^{3} \mathrm{TCID}_{50} / \mathrm{m} l[\mathrm{l}]$. After virus adsorption for 1 hour at $37^{\circ} \mathrm{C}$, the cells were diluted with medium 199 containing $10 \%$ calf serum to a concentration of $6 \times 10^{5}$ cells $/ \mathrm{m} l$ and $15 \mathrm{ml}$ of the suspension were plated in $90 \times 15 \mathrm{~mm}$ dishes, which contained 3 or 4 coverslips, and incubated in a $5 \% \mathrm{CO}_{2}$ incubator at $37^{\circ} \mathrm{C}$. When the inclusion bodies appeared in more than $10 \%$ of the cells, usually 24 to 30 hours after infection, the cultures were frozen-thawed three times, collected in centrifuge tube, sonicated with an Insonator M200 (Kubota, Tokyo) at $10 \mathrm{Kc}, 120 \mathrm{~W}$ for $5 \mathrm{~min}$ and clarified by centrifugation at $1,500 \times \mathrm{g}$ for $30 \mathrm{~min}$. The titer of FPLV thus prepared was $10^{3.2} \mathrm{TCID}_{50} /$ $\mathrm{m} l$.

Preparation of labeled FPLV with $\left[{ }^{3} \mathrm{H}\right]$-thymidine

About $1.5 \times 10^{8}$ cells suspended in $10 \mathrm{~m} l$ of medium 199 were infected with $10 \mathrm{~m} l$ of the virus, diluted to $240 \mathrm{~m} l$ with the medium 199 containing $10 \%$ calf serum and incubated at $37^{\circ} \mathrm{C}$ as mentioned above. Twelve hours after infection, the medium was replaced with $6 \mathrm{~m} l$ per plate of medium 199 containing $3 \%$ calf serum and $2.5 \mu \mathrm{Ci} / \mathrm{ml}$ of thymidine-[methyl- $\left.\mathbf{H}^{3}\right] \quad\left(\left[{ }^{3} \mathbf{H}\right]-\mathbf{T d R}\right.$, New England $\mathrm{Nu}$ clear, $20 \mathrm{Ci} / \mathrm{mmol}$ ). The cells were again incubated at $37^{\circ} \mathrm{C}$ until more than $10 \%$ of the cells contained the inclusion bodies. The culture fluid containing cells was harvested. Labeled FPLV was concentrated and partially purified as follows. Solid polyethylene glycol and $\mathrm{NaCl}$ were added to the culture fluid to give a final concentration of $10 \%$ and $0.5 \mathrm{M}$, respectively, and the fluid was stirred at $4^{\circ} \mathrm{C}$ overnight. After centrifugation at $8,000 \times \mathrm{g}$ for 15 min, the precipitate was suspended in $8 \mathrm{ml}$ of Hanks' balanced salt solution (HBS), frozen-thawed three times, followed by treatment with pancreatic DNase I (Miles Laboratory Ltd., specific activity: $810 \mathrm{u} / \mathrm{mg}$ ) at $4^{\circ} \mathrm{C}$ overnight, trypsin at $37^{\circ} \mathrm{C}$ for $20 \mathrm{~min}$ and then sodium deoxycholate at $37^{\circ} \mathrm{C}$ for $5 \mathrm{~min}$ at a final concentration of $100 \mu \mathrm{g} / \mathrm{ml}, 0.5 \%$ and $0.5 \%$, respectively. Large debris in the suspension were removed by centrifugation at $1,500 \times \mathrm{g}$ for $15 \mathrm{~min}$. The supernatant obtained was centrifuged on the cushion of $1 \mathrm{~m} l$ of $20 \%$ sucrose at $100,000 \times \mathrm{g}$ for 2 hours. The pellet was suspended in $4 \mathrm{~m} l$ of HBS. The density of the suspension was adjusted with solid $\mathrm{CsCl}$ to $1.39 \mathrm{~g} / \mathrm{cm}^{3}$, and centrifuged at $80,000 \times \mathrm{g}$ for 20 hours in a rotor SW50E. The virus recovered from the gradient was dialyzed to PBS. The titer of $\left[\mathrm{H}^{3}\right]$-TdR labeled FPLV thus obtained was $10^{4.2} \mathrm{TCID}_{50} / \mathrm{m} l, 1.7 \times 10^{4} \mathrm{cpm} / \mathrm{ml}$. The infectivity titers of the virus were measured by the method as described elsewhere [1].

\section{Examination of inclusion bodies}

The cells grown on the coverslips were withdrawn at various times after infection, and washed, fixed and stained with May-Grünwald-Giemsa (M-G-G) as described previously $[1,12]$. About 400 cells in 10 to 15 random fields were examined. The ratio of the cells containing inclusion body was expressed as a percent of the cells examined.

\section{Preparation of synchronized cultures}

All cultures were prepared in $35 \times 10 \mathrm{~mm}$ plastic plates except as mentioned above.

$G_{1}$ phase cell cultures: When cell cultures became confluent monolayer, the medium was replaced with medium 199 containing $1 \%$ calf serum and incubated at $37^{\circ} \mathrm{C}$. The rate of DNA synthesis in the cultures was examined at various time after medium change. When the DNA synthesis of the cultures became low and reached a constant level, the cultures were used as $G_{1}$ phase cell cultures.

Early S phase cell cultures: After 10 hours of plating, the cultures were used as partially synchronized early $S$ phase cultures. To prepare the early $S$ phase arrested cultures, after 5 to 10 hours of plating, the medium was replaced with medium 199 containing $2 \mathrm{mM}$ TdR supplemented with $10 \%$ calf serum and further incubated for 24 hours. This TdR treatment has been shown to completely inhibit deoxycytidylate kinase and block DNA synthesis [18], and thereby cells treated are arrested at the early $\mathrm{S}$ phase. The cells were washed twice with LE and again incubated in medium 199 containing $10 \%$ calf serum to allow the cell cycle to proceed.

$M$ phase cells: The cell cultures in $2 \mathrm{mM}$ TdR supplemented medium were prepared in $50 \mathrm{ml}$ Roux bottles by the same method described in the $S$ phase cell cultures. After incubation for 24 hours, the medium was replaced with Eagle's minimum essential medium free of $\mathrm{Ca}^{++}$containing $10 \%$ calf serum essentially according to Robbins and Marcus [10] and further incubated at $37^{\circ} \mathrm{C}$. At 8 to 10 hours after medium change, the bottle was shaken vigorously to detach mitotic cells [16]. The mitotic cells were collected by centrifugation at 1,000 rpm for $5 \mathrm{~min}$. More than $80 \%$ of the cells thus prepared were in mitosis. The mitotic index was de- 
termined as follows. The collected cells were fixed with Carnoy's fluid and allowed to stand for $15 \mathrm{~min}$, then centrifuged at $1,000 \mathrm{rpm}$ for $5 \mathrm{~min}$. This procedure was repeated twice. Finally, the precipitate was suspended in $2 \mathrm{~m} l$ of Carnoy's fluid, and one to two drops of the suspension were spread on a microscope slide. The preparatoin was stained with M-G-G. The cells in mitosis were scored per 400 to 500 cells of stained preparation.

Assay of DNA synthesis in cultured cells

For the determination of DNA synthesis, the cultured cells in plates were incubated for $30 \mathrm{~min}$ in medium 199 containing $0.5 \mu \mathrm{Ci} / \mathrm{m} l$ of $\left[{ }^{3} \mathbf{H}\right]$ - TdR and $1 \%$ calf serum for $30 \mathrm{~min}$ at $37^{\circ} \mathrm{C}$, then washed twice with LE, and lysed with $0.5 \mathrm{ml}$ of $0.6 \%$ sodium dodecyl sulfate, $0.01 \mathrm{M}$ EDTA and $0.01 \mathrm{M}$ Tris-HCl pH 7.2. The viscous cell lysate in plates were carefully transferred to centrifuge tubes, after which, the plates were washed with $0.5 \mathrm{ml}$ of LE, the washings also transferred to the same tubes. Two $\mathrm{m} l$ of $20 \%$ cold trichloroacetic acid (TCA) was added to the tubes and the mixtures were agitated by a Thermomixture (Thermonics, Tokyo). After standing at 0 to $4^{\circ} \mathrm{C}$ for $15 \mathrm{~min}$, the mixtures were centrifuged at $2,000 \mathrm{rpm}$ for $10 \mathrm{~min}$. The precipitates were washed twice with $4 \mathrm{ml}$ of $16 \%$ cold TCA and three times with $4 \mathrm{ml}$ of $5 \%$ cold TCA. The final precipitates were dissolved in $0.5 \mathrm{~m} l$ of $1 \mathrm{~N}$ $\mathrm{NaOH}$, and $0.2 \mathrm{~m} l$ of the solution were transferred to vials, neutralized with $0.2 \mathrm{ml}$ of $1 \mathrm{~N} \mathrm{HCl}$ and mixed with $5 \mathrm{ml}$ of toluene-Triton X100 scintilla-

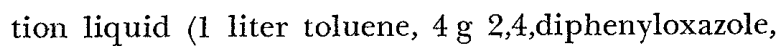
$0.1 \mathrm{~g} \mathrm{1,4-[5-phenyloxazolyl]-benzen,} 500 \mathrm{ml}$ Triton $\mathrm{X} 100)$. Radioactivities were measured in a liquid scintillation spectrometer (Horiba LS-50, Horiba, Kyoto). The remaining solution was used for a determination of protein content by the method of Lowry et al. [7]. Radioactivity was expressed as counts per $\min (\mathrm{cpm})$ per $100 \mu \mathrm{g}$ protein.

\section{Autoradiography}

To determine the DNA-synthesizing cells, the cultured cells on coverslips were incubated in medium 199 containing $1 \mu \mathrm{Ci} / \mathrm{m} l$ of $\left[{ }^{3} \mathrm{H}\right]-\mathrm{TdR}$ and $1 \%$ calf serum in the $\mathrm{CO}_{2}$ incubator for 1 hour at $37^{\circ} \mathrm{C}$, then washed once wtih PBS at $4^{\circ} \mathrm{C}$, fixed with 3 volumes of acetic acid and 1 volume of ethanol for $30 \mathrm{~min}$ at $4^{\circ} \mathrm{C}$, air-dried, mounted on a microscope slide, dipped in NR-M2 Sakura photographic emulsion (Konishiroku Photo Ltd., Tokyo), and exposed for 7 days. The silver grains containing cells were scored as DNA-synthesizing cells and expressed as a percent of the total scored cells in 4 coverslips ( 400 to 500 cells per coverslip).

\section{Results}

Synchronization of $\mathrm{KK}$ cell cultures

The degree of synchronization of $\mathrm{KK}$ cell cultures used in this study was determined. $\mathrm{G}_{1}$ phase cell cultures: The DNA synthesis of confluent cell cultures decreased rapidly from 0 to 24 hours after changing the medium 199 containing $1 \%$ calf serum, and then maintained almost constant level at 48 and 72 hours (Fig. 1). The cultures incubated in the medium 199 containing $1 \%$ calf serum for 48 hours were used as $G_{1}$ phase cell cultures.

Partially synchronized early $S$ phase cell cultures: After plating, DNA synthesis in the cells began to increase from 12 hours and reached the maximum at 24 hours and about $20 \%$ of the cells were in S phase at that time (Fig. 2). The cultures incubated for 10 hours after plating were used as partially synchronized early $S$ phase cultures. The maximum DNA synthesis of early $\mathrm{S}$ phase arrested cell cultures was observed 4 hours after removal of $2 \mathrm{mM} T \mathrm{~T} R$, and

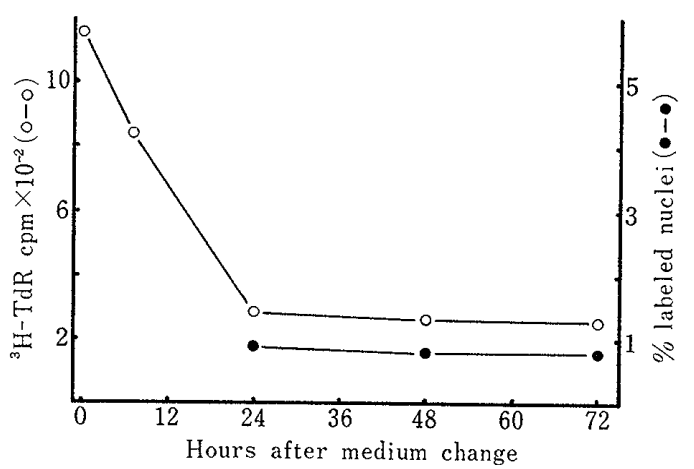

Fig. 1. DNA synthesis in the KK cells in the $1 \%$ calf serum containing medium. The medium of the KK cell cultures in $35 \times 10 \mathrm{~mm}$ plastic plates was replaced with medium 199 containing $1 \%$ calf serum after reaching confluency. The cells were labeled with 0.5 $\mu \mathrm{Ci} / \mathrm{m} l$ of $\left[{ }^{3} \mathrm{H}\right]-\mathrm{TdR}$ for $30 \mathrm{~min}$ at indicated time after medium change. Radioactivity of $\left[{ }^{3} \mathrm{H}\right]$ incorporated into acid insoluble materials was counted as in the text. For the autoradiography, cells were labeled with $1 \mu \mathrm{Ci} /$ $\mathrm{ml}$ of $\left[{ }^{3} \mathrm{H}\right]-\mathrm{TdR}$ for 1 hour. 


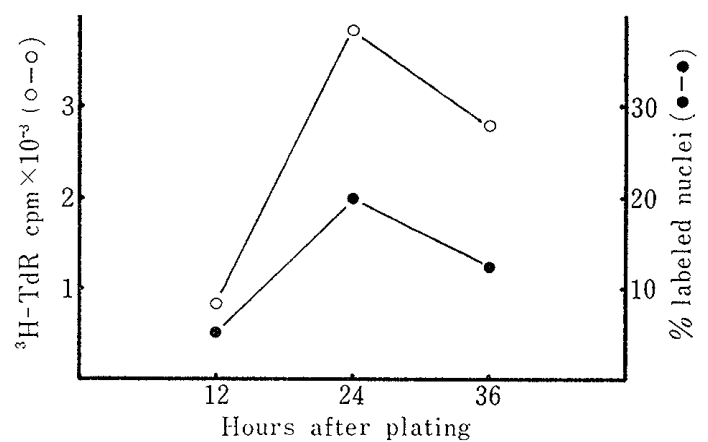

Fig. 2. DNA synthesis in $\mathrm{S}$ phase cells. Two $\mathrm{ml}$ each of the cell suspension $\left(5 \times 10^{5} / \mathrm{ml}\right)$ in $10 \%$ calf serum containing medium was seeded in $35 \times 10 \mathrm{~mm}$ plates. The cells were labeled with $\left[{ }^{3} \mathrm{H}\right]-\mathrm{TdR}$ at the time indicated after plating. Radioactivity of $\left[{ }^{3} \mathrm{H}\right]$ incorporated into acid insoluble materials was counted as in the text.

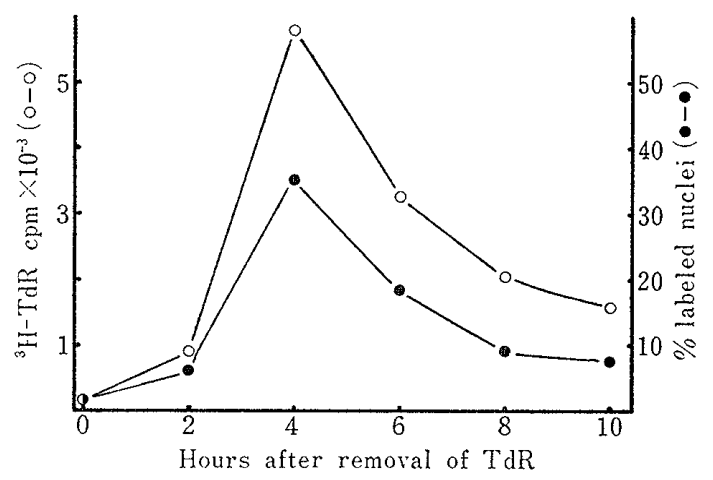

Fig. 3. DNA synthesis in the KK cellls released from early $S$ phase. The KK cells arrested in eary $S$ phase with $2 \mathrm{mM} \mathrm{TdR}$ (see in the text) were washed twice with LE and incubated in $10 \%$ calf serum containing medium. The cells were labeled affer medium change. Radioactivity of $\left[{ }^{3} \mathrm{H}\right]$ incorporated into acid insoluble materials was counted as in the text.

at this time, $35 \%$ of the cells showed apparent labeled nuclei (Fig. 3).

M phase cells: Eighty \% of the cells prepared were in mitotic phase.

\section{Adsorption experiment}

Adsorption of $\left[{ }^{3} \mathrm{H}\right]$-TdR labeled FPLV to the synchronized cells was measured by the relative values between the input and adsorbed cpm to the cells. Each of the $G_{1}$, early $S$ arrested and $M$ phase cells at a
Table 1. Uptake of $\left[{ }^{3} \mathrm{H}\right]-\mathrm{TdR}$-labeled FPLV into $G_{1}$, early $S$ and $M$ phase cells

\begin{tabular}{cccc}
\hline Cells & Input cpm & cpm adsorbed & $\begin{array}{c}\text { adsorbed } \\
\%\end{array}$ \\
\hline$G_{1}\left(5 \times 10^{5}\right)$ & $1.7 \times 10^{3}$ & $3.66 \times 10^{2}$ & 21.52 \\
early $S\left(4 \times 10^{5}\right)$ & $1.7 \times 10^{3}$ & $3.82 \times 10^{2}$ & 22.53 \\
$M\left(4 \times 10^{5}\right)$ & $1.7 \times 10^{3}$ & $2.75 \times 10^{2}$ & 16.17 \\
\hline
\end{tabular}

concentration of 4 to $5 \times 10^{5}$ cells per plate or tube were infected with $0.1 \mathrm{~m} l$ of the labeled virus $\left(1.7 \times 10^{3} \mathrm{cpm}\right)$. After adsorption for 1 hour at $37^{\circ} \mathrm{C}$, the cells were washed twice with $2 \mathrm{ml}$ of PBS to remove unadsorbed virus and then lysed with $0.5 \mathrm{ml}$ of $1 \mathrm{~N} \mathrm{NaOH}$ at $37^{\circ} \mathrm{C}$ for $30 \mathrm{~min}$. The radioactivity of the lysates was measured. There was no significant difference in the adsorption rate of the virus among 3 phases of the synchronized cells, although the value was slightly lower in the $M$ phase cells (Table 1).

Multiplication of FPLV in synchronized cell cultures

The appearance of the FPLV specific inclusion body was examined as an indicator of the evidence for the multiplication of the virus in the following experiments.

$\mathrm{G}_{1}$ phase cell cultures: The cultured cells on coverslips in the plates, previously arrested in the $G_{1}$ phase, were infected with $0.1 \mathrm{~m} l$ of FPLV $\left(10^{3.2} \mathrm{TCID}_{50} / \mathrm{ml}\right)$. After adsorption for 1 hour at $37^{\circ} \mathrm{C}, 2 \mathrm{~m} l$ of medium 199 containing $1 \%$ calf serum was added, and the cultures were incubated at $37^{\circ} \mathrm{C}$. At 12, 24 and 36 hours after infection, the coverslips were withdrawn for the determination of the presence of inclusion bodies, however they were not detected at any time during the incubation period (Fig. 4). This result suggests that the KK cells arrested in the $G_{1}$ phase did not support the replication of FPLV. To examine the effect of continued cell cycle from $G_{1}$ phase on virus multiplication, infected cells 


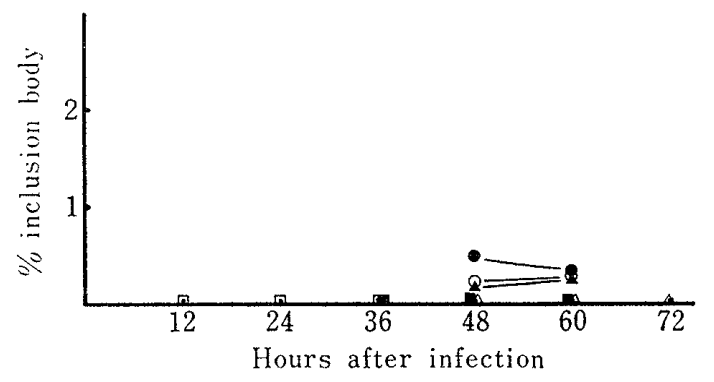

Fig. 4. Multiplication of FPLV in $G_{1}$ phase cells. $G_{1}$ phase cells were infected with FPLV and incubated in $1 \%$ calf serum containing medium ( $\square)$. The infected cells were trypsinized, suspended in $10 \%$ calf serum containtng medium and plated at $0(0), 6(0), 12(4)$, $24(\mathrm{Di})$ and $36 \mathrm{hr}(\Delta)$ after infection. Coverslips withdrawn at indicated time after infection were examined for the inclusion body.

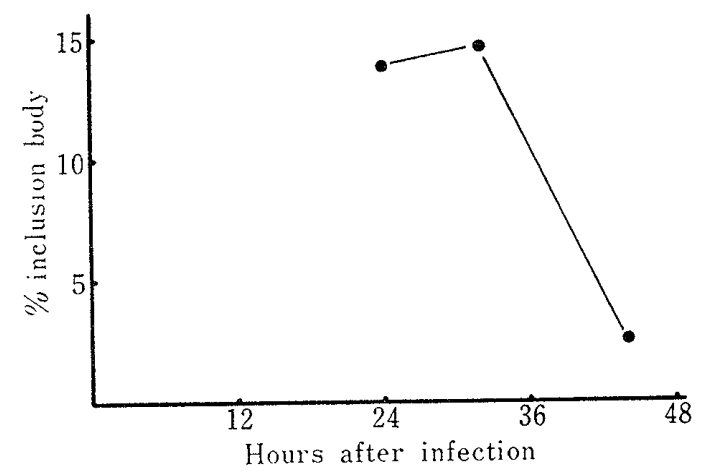

Fig. 5. Multiplication of FPLV in S phase cells. After $10 \mathrm{hr}$ of plating (see Fig. 2), the cells were infected with FPLV and incubated in $10 \%$ calf serum containing medium. The coverslips withdrawn at indicated time after infection were examined for the inclusion dody.

were trypsinized at $0,6,12,24$ and 36 hours after infection and were incubated in medium 199 containing $10 \%$ calf serum (Fig. 4). The inclusion bodies were found in less than $0.5 \%$ of the cells trypsinized at 0,6 and 12 hours, but not in those cells at 24 and 36 hours.

$\mathrm{S}$ phase cell cultures: After 10 hours of plating, the coverslip cultures in the plates (Fig. 2) were infected with $0.1 \mathrm{ml}$ of FPLV for 1 hour at $37^{\circ} \mathrm{C}$, then incubated in $2 \mathrm{ml}$ of medium 199 containing $3 \%$ calf serum. As shown in Figure 5, about 14 to $15 \%$ of the cells contained the inclusion body 24 to 30 hours after infection. The number of cells containing inclusion body decreased after 44 hours of infection.

M phase cell cultures: About $5 \times 10^{5}$ of $\mathrm{M}$ phase cells were suspended in $0.1 \mathrm{ml}$ of FPLV and incubated at $37^{\circ} \mathrm{C}$ for 1 hour, then diluted with $2 \mathrm{ml}$ of medium containing $1 \%$ calf serum and plated. The coverslips were withdrawn at various times from 12 to 48 hours after infection and examined for inclusion body. Throughout the observation period, no inclusion body was detected. Therefore, $M$ phase cells did not support the replication of FPLV.

Multiplication of FPLV in cell cultures arrested in early $S$ phase

FPLV could grow in the cells infected in early $S$ phase as in the above described experiment. Therefore, the purpose of this article is to determine whether growth of FPLV requires physiological function, such as a cellular DNA synthesis. The cell cultures arrested at early $S$ phase with $2 \mathrm{mM}$ TdR were infected with $0.1 \mathrm{~m} l$ of FPLV. After adsorption for 1 hour at $37^{\circ} \mathrm{C}, 2 \mathrm{~m} l$ of medium 199 containing $2 \mathrm{mM} \mathrm{TdR}$ and $10 \%$ calf serum were added to the cultures to arrest again in the early $S$ phase. To allow the cell cycle to proceed, the medium was replaced with $\mathrm{TdR}$ free medium at 0 , $6,12,20,30$ and 44 hours after infection. The coverslip cultures withdrawn at each observation time were stained and examined for inclusion body. Figure 6 shows that about 10 to $16 \%$ of the cells replaced with TdR free medium at 6 and 12 hours had inclusion bodies through 24 to 36 hours after infection and that the rate of the cells having the inclusion body decreased 4 to $8 \%$ at 44 hours. By contrast, in the cells arrested in the early $S$ phase for 20,30 and 44 hours, only 2 to $8 \%$ of the cells showed 


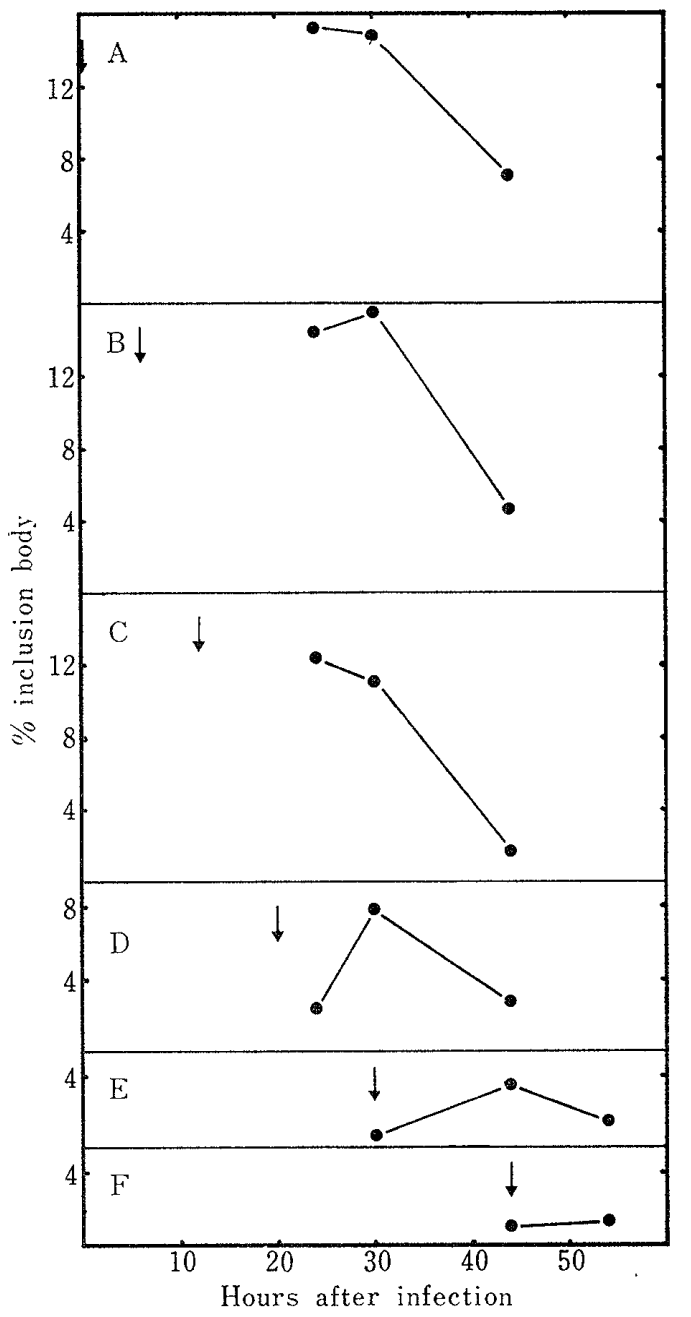

Fig. 6. Multiplication of FPLV in early $S$ arrested cells. The cells arrested in early $S$ phase with $2 \mathrm{mM}$ TdR were infected with FPLV. The cells were washed twice with LE and reincubated in TdR free medium at $O(A), 6(B)$, $12(C), 20(D), 30(E)$ and $44 \mathrm{hr}(F)$ after - infection as indicated by arrows. The coverslips were withdrawn at indicated time affer infection and examined for the inclusion body.

inclusion bodies during the observation period from 24 to 68 hours after infection. It seems that postponing the initiation of DNA synthesis after infection caused apparent reduction of the inclusion body formation. These results suggest that early $S$ phase cells themselves can not support the replication of FPLV and that DNA synthesis of host cells is also required for the replication of the virus.

\section{Discussion}

In the present report, the interaction of FPLV replication and the synchronized $\mathrm{KK}$ cells was studied because of the poor yield of the virus in ordinary cultured cells. Virus adsorption to the cell is one of the important steps necessary for the virus replicating process. In the adsorption of $\left[{ }^{3} \mathrm{H}\right]$-TdR labeled FPLV to the synchronized $\mathrm{KK}$ cells, a similar proportion of radioactive virus was taken up by each of the $\mathrm{G}_{1}$, early $\mathrm{S}$ and $\mathrm{M}$ phase of the cultures. The ratios ranged from 16.2 to $22.5 \%$. These values were remarkably low as compared to that of the $90 \%$ of Kilham rat virus taken up by the asynchronous culture of rat nephroma cell [11]. Though it should be noted that input multiplicity of the labeled virus was low in this study, the low rate of adsorption of FPLV may be responsible for the poor replication of the virus in $\mathrm{KK}$ cells. The study on the adsorption rate in different passage of $\mathrm{KK}$ cells and high titer FPLV may offer a clue for clarifying the poor replication of this virus in tissue cultures, because of the decreased FPLV yield observed in high passage level of $\mathrm{KK}$ cells [4].

In synchronized $\mathrm{KK}$ cells, the $\mathrm{G}_{1}$ phase cell cultures could not support the replication of FPLV when they were arrested for 12 to 36 hours after the virus infection. The viral replication, however, was observed in less than $0.5 \%$ of the cells after 48 to 60 hours of infection when cell cycle was allowed to proceed by trypsinizing $\mathrm{G}_{1}$ phase cells at 0 to 12 hours after infection. When DNA synthesis was allowed to proceed by the removal of $2 \mathrm{mM}$ TdR within 20 hours, especially within 12 hours after infection (Fig. 6 A, B and C), a higher yield of FPLV inclusion bodies was observed. FPLV multiplication was very poor in the early $S$ phase 
cell cultures in which DNA synthesis had been inhibited for 30 to 44 hours after infection. If the early $\mathrm{S}$ phase arrested cells which are inhibited DNA synthesis support the multiplication of FPLV, more cells should contain inclusion body in the samples of Figure 6, E and $\mathrm{F}$ at 30 and 44 hours, respectively. After virus inoculation to $G_{1}$ phase cells and trypsinization of the infected cells within 12 hours, the inclusion bodies appeared very late and in a low percentage as compared to those in the early $S$ phase cells. This could be attributed to the long time required for the $G_{1}$ phase cells to enter $S$ phase after trypsinization. It is also possible that not all trypsinized $\mathrm{G}_{1}$ phase cells resulted in $\mathrm{S}$ phase cells. The number of cells containing the inclusion body decrease in proportion to prolongation of time arrested at the early $\mathrm{S}$ phase after infection. This fact suggests that FPLV genome could not retain its biological activity for long time in the infected KK cells. That FPLV genome is unstable in $\mathrm{KK}$ cells may be responsible for the poor yield of the virus in the tissue cultures. It had been reported, however, that adeno-associated virus type 1 genome was retained without loss of activity even after many passages of $\mathrm{KB}$ cells latently infected with the virus [3].

There are many previous studies on the probable role of the DNA synthesizing system of the host cells for the replication of parvoviruses. As for the multiplication of Kilham rat virus in rat embryo cells, the cells which started DNA synthesis at the time of infection provided optimal condition for viral replication $[14,15]$. Infection of $\mathrm{H}-1$ virus at the beginning of the $\mathrm{S}$ phase of rat [2] or hamster [9] embryo cells, led to the production of considerably more virus than in later infection in the $\mathrm{S}$ phase or the $\mathrm{G}_{2}$ phase. In the interaction of bovine parvovirus and fetal bovine spleen cells, the production of infectious progeny virus proceeded at a faster rate in synchronized cells infected at the beginning of the $S$ phase than in asynchronous cultures [8]. In the present study, FPLV also requires the DNA synthesizing system of the host cells for its own replication. This agrees with the report that the virus replicates mainly in the actively dividing cells of organs like the mucosa of the intestinal tract and the bone marrow of susceptible animals. [6].

Acknowledgment. We thank Dr. Y. H. Nakanishi, Department of Experimental Radiobiology, Faculty of Veterinary Medicine, Hokkaido University, Sapporo, for his helpful technical advice.

\section{References}

[1] Goto, H., Yachida, S., Shirahata, T., and Shimizu, K. (1974). Feline panleukopenia in Japan. I. Isolation and characterization of the virus. Jpn. J. Vet. Sci. 36, 203-211.

[2] Hampton, E. G. (1970). H-I virus growth in synchronized rat embryo cells. Canad. J. Microbiol. 16, 266-268.

[3] Handa, H., Shiroki, K., and Shimojo, H. $(1977)$. Establishment and characterization of KB cell line latently infected with adenoassociated virus type 1. Virology 82, 84-92.

[4] Johnson, R. H. (1965). Feline panleukopenia virus. II. Some features of the cytopathic effects in feline kidney monolayers. Res. Vet. Sci. 6, 472-481.

[5] Johnson, R. H. (1967). Feline panleukopenia virus. IV. Methods for obtaining reproducible in vitro results. Res. Vet. Sci. 8, 256-264.

[6] Langheinrich, K. A., and Nielsen, S. W. (1971). Histopathology of feline panleukopenia: A report of 65 cases. J. Am. Vet. Med. Assoc. 158, 863-872.

[7] Lowry, O. H., Rosebrough, N. J., Farr, A. L., and Randall, R. J. (1951). Protein measurement with Folin phenol reagent. J. Biol. Chem. 193, 265-275.

[8] Parris, D. S., and Bates, R. C. (1976). Effect of bovine parvovirus replication on DNA, RNA and protein synthesis in $S$ phase cells. Virology 73, 72-78.

[9] Rhode, S. L., III. (1973). Replication process of the parvovirus H-1. I. Kinetics in a parasynchronous cell system. J. Virol. 11, 856-861.

[10] Robbins, E., and Marcus, P. I. (1964). Mito- 
tically synchronized mammalian cells: A simple method for obtaining large populations. Science 144, 1152-1153.

[11] Salzman, L. A., White, W. L., and Mckerle, L. (1972). Growth characteristics of Kilham rat virus and its effect on cellular macromolecular synthesis. J. Virol. 10, 573-577.

[12] Scott, F. W., Csiza, C. K., and Gillespie, J. H. $(1970)$. Feline viruses. V. Serum-neutralization test for feline panleukopenia. Cornell Vet. 60, 183-191.

[13] Siegl, G., and Gautschi, M. (1973). The multiplication of parvovirus $\mathrm{Lu}$ III in a synchronized culture system. I. Optimum condition for virus replication. Arch. Gesamte Virusforsch. 40, 105-118.

[14] Tennant, R. W., and Hand, E. R. (1970). Re- quirement of cellular synthesis for Kilham rat virus replication. Virology 42, 1045-1063.

[15] Tennant, R. W., Layman, K. R., and Hand, R. E. (1960). Effect of cell physiological state on infection by rat virus. J. Virol. 4, 872-878.

[16] Terashima, T., and Tolmach, T. L. (1963). Growth and nucleic acid synthesis in synchronously dividing population of HeLa cells. Exp. Cell Res. 30, 344-362.

[17] Youngner, J. S. (1954). Monolayer tissue cultures. I. Preparation and standardization of suspension of trypsin-dispersed monkey kidney cells. Proc. Soc. Exp. Biol. Med. 85, 202205.

[18] Xexos, N. (1962). Deoxyriboside control and synchronization of mitosis. Nature 194, 682683.

要 約

ネコ汎白血球減少症ウイルスのネコ腎同調培養細胞に抢ける增殖：遠藤 実・*品川森一・後藤 仁・

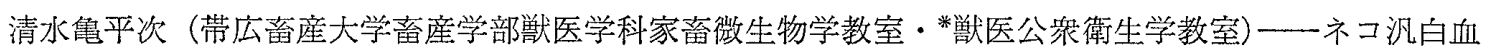
球減少症ウイルス (FPLV) の同調培養ネコ腎細胞における增殖を調べた. $\left[{ }^{3} \mathrm{H}\right]$ チミジン標識 FPLVを 用いて調へた $\mathrm{G}_{1} ， \mathrm{~S} ， \mathrm{M}$ の各細胞周期の細胞へのウイルスの吸着には, 細胞周期による差注められ なかった， $\mathrm{G}_{1}$ 期の細胞に FPLV を感染させ，細胞をそのまま $G_{1}$ 期に止めた場合 FPLV の増殖は認 められなかった。しかし感染後12時間までにトリプシン処理により細胞の周期を先に進めるとごくわず かであるがウイルスの増殖が観察されたＳＳ期の細胞にウイルスを感染させた場合に，もっともよくウ イルスが増殖した。 $2 \mathrm{mM}$ のチミシン処理により $\mathrm{S}$ 前期に周期を止めた細胞にウイルスを感染させた とき，感染後12時間までにチミジンを除き細胞周期を進めると，S 期に感染させた場合と同様にウイル スは増殖した。しかし感染後もチミジン処理を続け細胞を $\mathrm{S}$ 期に止めた場合ウイルス増殖は抑制され た、M期の細胞に感染させた場合にはウイルスの増殖は認められなかった，以上の結果は FPLVがそ の堌殖に宿主の活動しているDNA 合成系を必要としていることを示している. 